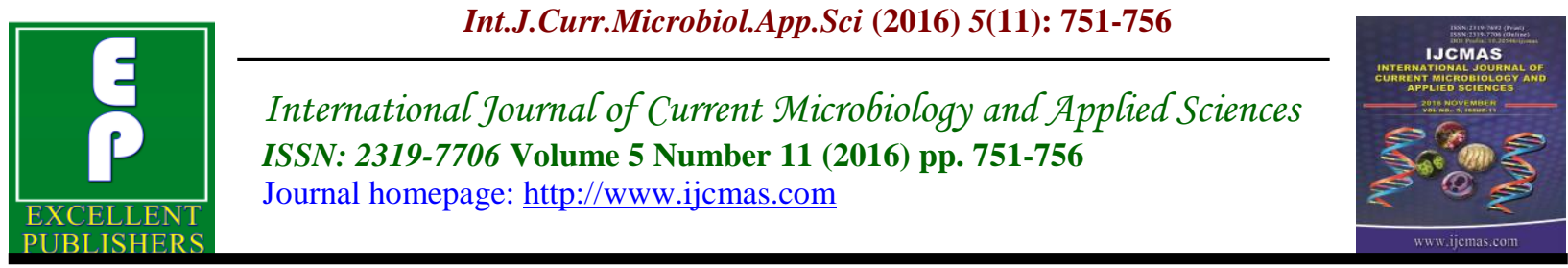

Original Research Article

http://dx.doi.org/10.20546/ijcmas.2016.511.086

\title{
Pectin Isolation from Dry Pod Husk Cocoa with Hydrochloride Acid
}

\author{
Gatot Siswo Hutomo*, Abdul Rahim¹ and Syahraeni Kadir \\ Department of Food Science, Faculty of Agricultural, Tadulako University, \\ Jln. Soekarno Hatta Km. 9 Palu Central Sulawesi, 94118 Indonesia \\ *Corresponding author
}

\begin{tabular}{|c|c|}
\hline & A B S T R A C T \\
\hline & \multirow{10}{*}{$\begin{array}{l}\text { Pectin was found in the part of the vegetables or fruits that it was in the pod husk } \\
\text { cacao contain } 11-15 \% \text { pectin in dry basis. Pectin isolation could be done with acid, } \\
\text { base or another solution look like ammonium sulphate. Dry pectin isolation with } \\
\text { hydrochloric acid applied temperature and time extraction were done by Respon } \\
\text { Surface Methodology (RSM) which each factor had } 5 \text { level with composite design. } \\
\text { Hydrochloric acid applied on level } 0.653,1,1.5,2 \text { and } 2.282 \mathrm{M} \text {, temperature } \\
\text { applied on level } 43.18,50,60,70 \text { and } 76.82^{\circ} \mathrm{C} \text {. Extraction time applied on level } \\
3.318,4,5,6 \text { dan } 6.282 \text { hours. The base on the optimization by RSM calculation } \\
\text { that was pectin recovery about } 12 \% \text { (wet basis) with condition hydrochloric acid } \\
1.58 \mathrm{M} \text {, Temperature } 62.28^{\circ} \mathrm{C} \text { and Extraction time } 4.80 \text { hours. The really dry pectin } \\
\text { extraction with condition hydrochloric acid } 1.58 \mathrm{M} \text {, temperature } 62.28^{\circ} \mathrm{C} \text { and } \\
\text { extraction time } 4.80 \text { hours by RSM that pectin extracted about } 11.70 \% \text {, with } \\
\text { methoxyl content } 58.45 \% \text {, galacturonate content } 49,87 \% \text { and clarity } 72 \% \text {. }\end{array}$} \\
\hline & \\
\hline & \\
\hline & \\
\hline & \\
\hline & \\
\hline & \\
\hline & \\
\hline & \\
\hline & \\
\hline
\end{tabular}

\section{Introduction}

Fruit of cacao contained seed, pulp and mesocarp or pod husk cacao, especially seed had high economies value which produced chocolate, fat and another products and the pod husk cacao as by product. Pod husk cacao is not to be used new product and unsuitable for animal feed because high cellulose crystallinity was not effectively to be digested. Pod husk cacao was potentially to be cellulose derivative and pectin source. Source of pectin look like Hazelnut Pill (Pardede et al., 2013), apple pomace (Wikiera et al., 2016), Tunisian pomegranate (Abid et al., 2016), orange peel (Hosseini et al., 2016).
Pectin contained in the pod husk cacao 11$15 \%$ dry base which potentially to extract as pectin powder. Pectin had an important role to support food industry, cosmetics and medicine. Pectin in food industry as functional food, gelling agent, emulsifier, dehydrating agent, colloids protective and stabilizer. Pectin act as change the viscosity of the solution that increasing the use of pectin (Yuliarti et al, 2015).

Pectin is a polymer of D-galacturonic acid with the 1.4 glycosidic bond (Nelson et al., 1977). Most of the carboxyl group in the polymer having pectin methyl esterification 
with (methylated) into methoxyl group, these compounds are referred to as acid pectinase or pectin. Acid pectinase together sugar and oxygen at high temperatures to form a gel as it did in jam or jelly. The degree of methylation or the carboxyl group is esterified with a methyl determines the temperature of gel formation.

The higher the degree of methylation of the high temperature gel formation. For making jam pectin needed to the degree of methylation of 74 , meaning that $74 \%$ of the carboxyl group experienced methylation. In the trade, the technical term jelly grade, i.e. the amount of sugar (lb) which is required for the formation of a gel by $1 \mathrm{lb}$ pectin.

Pectin is found in many cells of space between fruits that serve as glue. Isolation of pectin can be done with a variety of solvents such as acetate acid, hydrochloric acid, nitric acid (Yapo and Koffi, 2013), sodium hydroxide, ammonium oxalate (Cut, 2013; Ismail et al., 2012) and other solvents. Isolation of pectin uses extruder screw can also be done (Hwang et al., 1988). Isolation pectin used Ultrasound assisted extraction (Grassino et al., 2016; Wang et al., 2016), The use of acid will dissolve into protopectin soluble in water. Precipitation pectin done using alcohol. The purpose of this study is to obtain the optimum conditions of isolation of pectin from cocoa pod husk cacao using hydrochloric acid.

\section{Materials and Methods}

\section{Materials}

Cacao is obtained from Palolo District Sigi Regency in Central Sulawesi Province Indonesia, which is the type of cocoa beans from a local or Forasterro called bulk cacao. Chemical material hydrochloric acid and alcohol absolut are proanalysis quality.

\section{Extraction of pectin from pod husk cacao}

The fruit then cut the cocoa pod husk of his shredded with a thickness of about $2 \mathrm{~mm}$ that was dried condition. Results slice isolation process using hydrochloric acid. Plan to use the Response Surface Methodology (RSM) with three factors each 5 levels with the level of $\mathrm{HCl} 0.653,1,1.5$, 2 and $2,28 \mathrm{M}$, long time insulation used is $3,318,4,5,6$ and 6,282 hours and the temperature insulation is $43.18,50,60,70$ and $76,82^{\circ} \mathrm{C}$, central composite design (Pinhiero et al., 2008). Furthermore, the results of verification optimization pectin is the isolation and characterization.

\section{Determination of yield, methoxyl and} clarity

The yield of pectin obtained from the percentage of pectin after the drying process of wet pectin.

$$
\text { Yield }=\frac{\text { Pectin }(\mathrm{g})}{\text { Pod husk cacao (wet) } \mathrm{g}}
$$

Methoxy levels defined as the amount of methanol contained in the pectin. Methoxy content of the pectin has an important role in determining the functional properties of pectin solution and can affect the structure and texture of pectin gel. Weighed 0.5 grams of dry pectin with $100 \mathrm{ml}$ of distilled water were added $2 \mathrm{ml}$ of $70 \%$ alcohol, then heated and shaken. After it has cooled, add 5 drops of phenol phtalien then titrated with $0.05 \mathrm{~N} \mathrm{NaOH}$. Equivalent point is marked with a color change from white to brownish pink. The volume of $\mathrm{NaOH}$ required is recorded (V1). Then added $20 \mathrm{ml}$ of concentrated $\mathrm{HCl}$ and shaken, then the solution is allowed to stand for 15 minutes. The solution was shaken until the pink color disappeared, and add 3 drops of phenol 
phtaline and titrated with $0.05 \mathrm{~N} \mathrm{NaOH}$ arise until the pink color (V2).

Methoxy $(\%)=(\mathrm{V} 2 \times \mathrm{N}-\mathrm{NaOH} \times 31 \times$ $100 \%) /($ Pectin g x 1000$)$

Galacturonate Content $(\%)=\left(\left(\mathrm{V}_{1}+\mathrm{V}_{2}\right) \mathrm{x}\right.$ $\mathrm{N}-\mathrm{NaOH} \times 31$ x 100\% )/(Pectin g x 1000$)$

Clarity was determained transmitten by spectrophotometer as Transmitten (\%). The Clarity was reflecting a purity as no colored substance dissolved.

\section{Results and Discussion}

\section{Dry pectin isolation from pod husk cocoa with HCL}

Effect of temperature and $\mathrm{HCl}$ in extraction of pectin from cocoa pod husk dry influence on the yield of pectin obtained. The high temperatures used for the extraction of pectin higher revenue yield of pectin obtained and vice versa if the low temperature extraction will yield a low pectin. Time is short extraction will yield a low pectin, whereas the longer the extraction of pectin will yield larger (Figure 1). Based on the analysis of Respon Surface Methodology with conditions for the extraction of pectin using $1.58 \mathrm{M} \mathrm{HCl}$ and extraction time was 4.80 hours.

The yield of the isolated pectin is strongly influenced by the time of extraction and concentration of $\mathrm{HCl}$ used. The higher the concentration of $\mathrm{HCl}$ is used in the extraction of pectin from cocoa pod husk cleaning will increase the yield of pectin to be obtained. To obtain a high yield of pectin with low concentrations of $\mathrm{HCl}$ will take a long time, and vice versa with a high concentration of $\mathrm{HCl}$ extraction of pectin needed time shorter (Figure 2). The concentration of $\mathrm{HCl}$ is higher with the longer time it will decrease yield of pectin obtained (Sulihono et al., 2012). So the isolation of pectin using $\mathrm{HCl}$ from the pod husk cocoa would the yield a high (12\%) at a concentration of $1.58 \mathrm{M} \mathrm{HCl}$ with temperatures $62,28^{\circ} \mathrm{C}$ based Response Surface Methodology.

Fig.1 Effects of Surface Plot Extraction Time and $\mathrm{HCl}$ Vs Yield Pectin Results of Dry Pectin Extraction from Pod Husk Cocoa

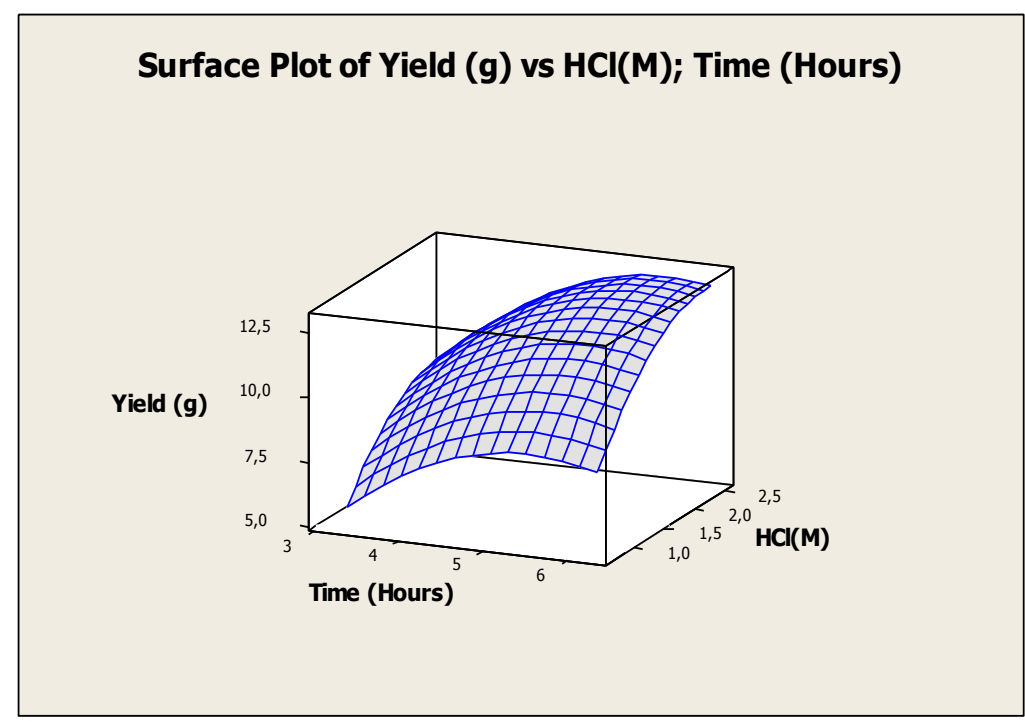


Fig.2 Effects of Surface Plot Temperature and $\mathrm{HCl}$ Vs Yield Pectin Results of Dry Pectin Extraction from Pod Husk Cocoa

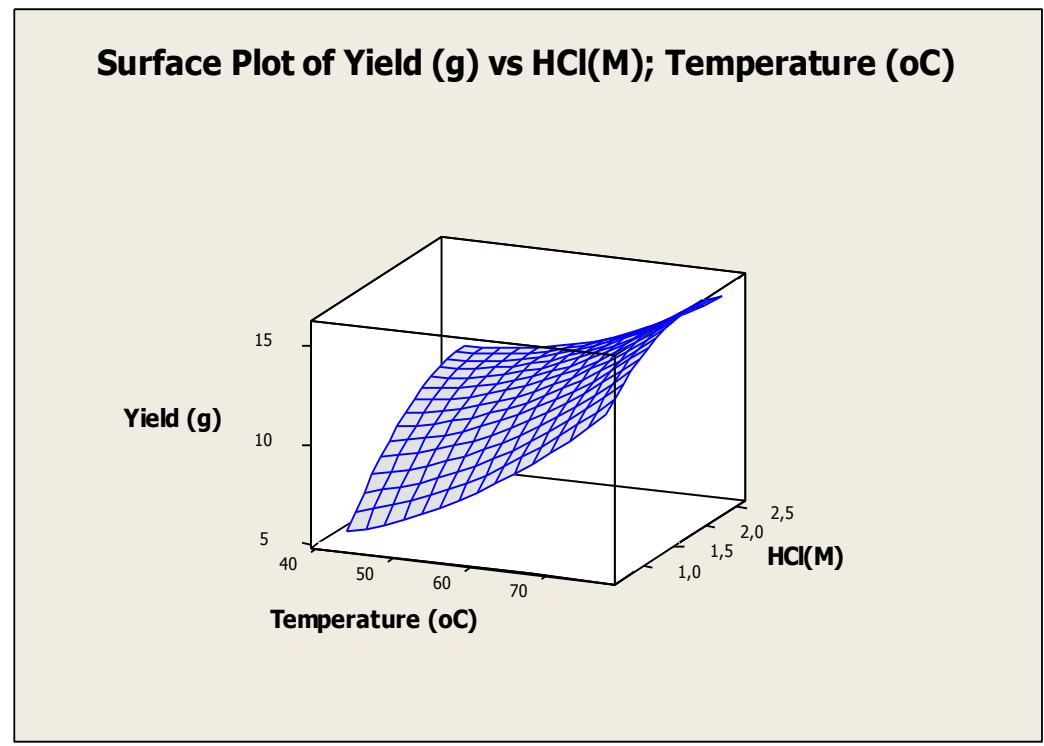

Fig.3 Effects of Surface Plot Temperature and Extraction Time Vs Yield Pectin Results of Dry Pectin Extraction from Pod Husk Cocoa

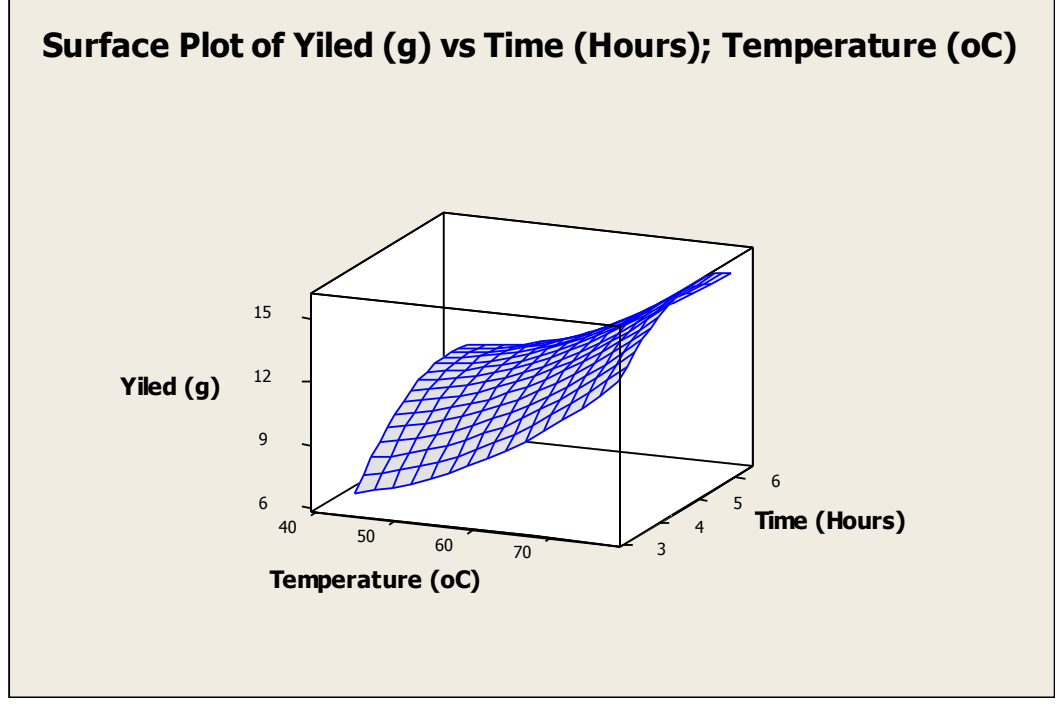

Effect of temperature and time of extraction is also very influential on the isolation of pectin. The low temperature in the extraction of pectin to produce a low yield as well, while the high temperatures during the extraction of pectin will be produced high yield of pectin. When the extraction of pectin long will produce a high yield of pectin, but the extraction time is too long it will yield slightly decreased pectin (Figure 3). The analysis obtained using Respon Surface Methodology with condition temperature $62,28^{\circ} \mathrm{C}$ and time of extraction for 4.80 hours produced the highest yield of pectin about $12 \%$. 
Isolation of pectin in dry conditions was needed higher temperatures as $62,28^{\circ} \mathrm{C}$, compared to the early research advances temperature used for wet isolation of the cocoa pod husk conditions and the concentration of hydrochloric acid used relatively the same. It is very possible for the release of pectin bind to tissues in the dry conditions would require a longer time compared with the pectin bound on the fresh plant tissue or wet.

In conclusion, isolation of pectin from cocoa pod husk dry conditions with hydrochloric acid $1.58 \mathrm{M}$, temperature of $62.28^{\circ} \mathrm{C}$ and extraction time was 4.80 hours, by Respon Surface Methodology calculation would pectin yeild about $12 \%$. After verification with reference to the condition of the pectin isolated yield of $11.70 \%$, with $58.45 \%$ of the methoxy content, galacturonate content $49,87 \%$ and has the clarity of $72 \%$.

\section{References}

Abid, M., C.M.G.C. Renard, A. A. Watrelot, Imen Fendri, Hamadi Attia, M.A. Ayadi, $2016 . \quad$ Yield and composition of pectin extracted from Tunisian pomegranate peel Int. J. Biol. Macromol., Volume 93, Issue null, Pages 186-194.

Cut Erika. 2013. Pectin Extraction From Pod Husk Cocoa (Theobroma Cacao L.) used Ammonium oxalate. J. Technol. Industry Indonesia, Vol. 2(5): 1-6.

Grassino, A.N., Mladen Brnčić, Dražen Vikić-Topić, Sunčica Roca, Maja Dent, Suzana Rimac Brnčić, 2016. Ultrasound assisted extraction and characterization of pectin from tomato waste. Food Chem., Volume 198, Issue null, Pages 93-100.

Hosseini, S.S., Faramarz Khodaiyan, Mohammad S.Y. 2016.Optimization of microwave assisted extraction of pectin from sour orange peel and its physicochemical properties Carbohydrate Polymers, Volume 140, Issue null, Pages 59-65.

Hwang, J.K., C.J. Kim and C.T. Kim. 1988. Extrusion of Apple Pomace Facilitates Pectin Extraction. J. Food Sci., 63(5): 841-844

Ismail, N.S., N. Ramli, N.M., Hani and Z. Meon. 2012. Extraction and Characterization of Pectin from Dragon Fruit (Hylocereus polyrhizus) using Various Extraction Conditions. Sains Malaysiana, 41(1): 41-45.

Nelson, D.B., Smith, C.J.B. and Wiles. 1977. Commecially important pectic substance. Inc. Wesport, Connecticut.

Pardede, A., D. Ratnawati, Agus Martono H.P. 2013. Extraction and characterization of pectin form Hazelnut Pill. (Alleurites mollucana Willd). J. Media SainS, Volume 1(5): 66-71.

Pinheiro, E.R., I.M.D.A. Silva, L.V. Gonzaga, E.R. Amante, R.F. Teófilo, M.M.C. Ferreira, and R.D.M.C. Amboni. 2008. Optimization of extraction of high-ester pectin from passion fruit peel (Passiflora edulis flavicarpa) with citric acid by using response surface methodology. J. Biores. Technol., 99(13): 55615566.

Sulihono, A., Benyamin Tarihoran, Tuti Emilia Agustina, 2012. Pengaruh Waktu Temperatur dan Jenis Pelarut Terhadap Ekstraksi Pektin Dari Kulit Jeruk Bali (Citrus maxima), J. Teknik, (4): 18.

Wang, M., Huang B., Fan C., Zhao K, Hu H., Xu X., Pan S., Liu F. 2016. Characterization and functional properties of mango peel pectin extracted by ultrasound assisted citric 
acid, Int. J. Biol. Macromol., Volume 91, Issue null, Pages 794-803.

Wikiera, A., Magdalena M., Anna Starzyńska-Janiszewska, Bożena S., 2016. Endo-xylanase and endocellulase-assisted extraction of pectin from apple pomace. Carbohydrate Polymers, Volume 142, Issue null, Pages 199-205.

Yapo, B.M., K.L. Koffi. 2013. Extraction and Characterization of Gelling and
Emulsifying Pectin Fractions from Cacao Pod Husk. J. Food and Nutrition Res., 1(4): 46-51.

Yuliarti, O., Kelvin K.T. Goh, Lara MatiaMerino, John Mawson and Charles Brennan, 2015. Extraction and characterisation of pomace pectin from gold kiwifruit (Actinidia chinensis). Food Chemistry, Volume 187, Issue null, Pages 290-296.

\section{How to cite this article:}

Gatot Siswo Hutomo, Abdul Rahim and Syahraeni Kadir. 2016. Pectin Isolation from Dry Pod Husk Cocoa with Hydrochloride Acid. Int.J.Curr.Microbiol.App.Sci. 5(11): 751-756. doi: http://dx.doi.org/10.20546/ijcmas.2016.511.086 